\title{
Analisis Kemampuan Komunikasi Matematis Ditinjau dari Tipe Kepribadian Guardian dan Idealist
}

\author{
Lekok Melya ${ }^{1 *}$, Nanang Supriadi ${ }^{1}$ \\ 1 Universitas Islam Negeri Raden Intan Lampung. Jalan Endro Suratmin, Sukarame, Bandar \\ Lampung 35133, Indonesia. \\ *Corresponding Author. E-mail: Melyalya05@gmail.com
}

Received : 13-08-2018; Revised : 19-09-2018; Accepted : 30-09-2018

\begin{abstract}
Abstrak
Penelitian ini bertujuan untuk menggambarkan kemampuan komunikasi matematis siswa SMA ditinjau dari tipe kepribadian guardian dan idealist. Metode yang dipakai dalam penelitian ini adalah metode desriptif kualitatif. Subjek dalam penelitian ini diambil menggunakan tekhnik purposive random sampling dua orang siswa dari kelas X SMA di Kota Bandar Lampung dengan tipe kepribadian berbeda yaitu satu siswa dengan tipe kepribadian guardian dan satu siswa dengan tipe kepribadian idealist yang diambil berdasarkan dimensi kepribadian David Keirsey. Hasil penelitian menunjukkan bahwa subjek dengan tipe kepribadian guardian hanya mampu menguasai lima kriteria kemampuan komunikasi matematis subjek tidak mampu membuat simpulan dengan bahasa sendiri, subjek dengan tipe kepribadian idealist mampu menguasai lima kriteria kemampuan komunikasi matematis namun subjek tidak menguasai kriteria ketiga yaitu subjek tidak mampu menuliskan alasan-alasan dalam menjawab soal. Sehingga dapat disimpulkan bahwa kecendrungan kemampuan komunikasi matematis siswa yang memiliki tipe kepribadian guardian dalam mengerjakan soal mampu menuliskan informasi yang ada dalam soal sambil membaca soal, dengan sangat memahami maksud dari soal tersebut sedangkan siswa yang memiliki tipe kepribadian idealist dalam mengerjakan soal mampu menuliskan informasi yang ada dalam soal, membaca soal dengan teliti untuk memahami maksud dari soal tersebut.
\end{abstract}

Kata Kunci : Kemampuan Komunikasi Matematis, Tipe Kepribadian

\begin{abstract}
The purpose of this study is to describe the mathematical communication skills of high school students in terms of guardian and idealist personality types. Subjects in this study were taken using a purposive random sampling technique of two students from class $X$ senior high school in Bandar Lampung with different personality types, that is one student with guardian personality type and one student with a idealist personality type based on David Keirsey's personality dimensions, with personality type initial guardian (NAP) and initial idealist personality type (DBD). Mathematical communication skills are analyzed based on the following criteria : (1) the ability to write down what is known and asked about the questions; (2) the ability to write answers according to the purpose of the questions; (3) the ability to write down reasons for answering questions; (4) the ability to make mathematical terms and symbols; (5) the ability to make images that are relevant to the questions; (6) the ability to make conclusions in their own language. The results showed that subjects with guardian personality type were only able to master the five criteria of mathematical communication ability. The subject was unable to conclude with his own language. The results showed that subjects with idealist personality type were only able to master the five criteria of mathematical communication ability but the subject does not master the third criterian, the subject is unable to write down the reasons for answering the question.
\end{abstract}

Keywords: Mathematical Communication Ability, Personality Type 


\section{PENDAHULUAN}

Komunikasi matematis memiliki peran yang sangat penting dalam pembelajaran matematika, karena dengan melalui komunikasi matematis dapat mengorganisasikan mengkonsolidasikan dan matematis siswa (Supriadi, 2015). Secara umum kemampuan komunikasi matematika dapat dilihat dari dua aspek yaitu komunikasi tulisan (writing) dan komunikasi lisan (talking). Kemampuan komunikasi tertulis dapat berupa gambar, tabel, grafik, soal maupun bentuk jawaban dalam bentuk tulisan lainnya. Sedangkan kemampuan komunikasi lisan dapat berupa pengungkapan dan penjelasan verbal suatu gagasan matematika seperti berbicara, mendengar, dan diskusi (Syahri, 2017).

Tingkah laku dari seseorang, merupakan cerminan hal yang nampak dari apa yang dipikirkan dan dirasakan oleh orang tersebut. Terdapat beberapa penelitian terdahulu yang telah mencoba untuk melihat kaitan antara perbedaan tingkah laku dalam proses pembelajaran diantaranya penelitian yang dilakukan oleh (Aziz, Kusmayadi, \& Sujadi, 2014) menunjukkan bahwa terdapat karateristik yang berbeda-beda pada proses pembelajaran. Dengan menyadari perbedaan kondisi pada masing-masing siswa, maka guru dapat memberikan metode mengajar terbaik untuk masingmasing pribadi siswa, dan kemampuan komunikasi mereka diselidik berdasarkan tipe kepribadian yang telah digolongkan berdasarkan pengelompokan oleh David Keirsey.

Berdasarkan beberapa penelitian terdahulu yang telah mencoba untuk melihat kaitan antara perbedaan tingkah laku dan perbedaan proses pemecahan masalah pada kesulitan metakognisi siswa diantaranya penelitian yang dilakukan oleh Vera Rosalina Bulu dengan tipe kepribadian Tipologi Hippocrates-Galenus (Bulu \& Slamet, 2015) dan dilakukan oleh Camelina Fitria dengan tipe kepribadian guardian, artisan, rational, dan idealist (Fitria, Sujadi, \& Subanti, 2016). Perbedaan dengan penelitian peneliti yaitu peneliti mencoba untuk melihat kaitan antara perbedaan tingkah laku pada tipe kepribadian guardian dan idealist dengan kemampuan komunikasi matematis.

Penelitian selanjutnya mencoba untuk melihat kaitan antara perbedaan tingkah laku dan perbedaan proses berpikir kreatif dalam pemecahan masalah matematis diantaranya penelitian yang dilakukan oleh Rizki Wahyu Yunian Putra dengan tipe kepribadian guardian dan idealis (Hasanah \& Putra, 2017) dan dilakukan oleh (Aziz et al., 2014) Abdul Aziz dengan tipe kepribadian dimensi myer-briggs. Perbedaan dengan penelitian peneliti yaitu peneliti mencoba untuk melihat kaitan antara perbedaan tingkah laku pada tipe kepribadian guardian dan idealist dengan kemampuan komunikasi matematis tanpa ada proses berpikir kreatif.

Uraian di atas menunjukkan adanya keterkaitan antara masing-masing tipe kepribadian terhadap kemampuan komunikasi matematis siswa, sehingga siswa dengan tipe kepribadian akan memiliki keterampilan berkomunikasi yang berbeda pula. Misalnya siswa dengan tipe kepribadian rational yang lebih suka penjelasan dengan logika dan mampu menangkap abstraksi dengan baik akan memudahkan siswa dalam menyelesaikan masalah atau siswa dengan tipe kepribadian guardian menghendaki instruksi yang mendetail dan prosedur yang teratur akan lebih mudah untuk membantu siswa dalam menyelesaikan masalah. Berdasarkan uraian yang telah disampaikan, penelitian 
ini bertujuan untuk: (1) mendeskripsikan kemampuan komunikasi matematis siswa kelas X SMA Muhammadiyah 2 Bandar Lampung yang mempunyai tipe kepribadian Guardian dalam menyelesaikan soal matematika; dan (2) mendeskripsikan kemampuan komunikasi matematis siswa kelas X SMA Muhammadiyah 2 Bandar Lampung yang mempunyai tipe kepribadian Rational dalam menyelesaikan soal matematika.

\section{METODE}

Metode yang dipakai dalam penelitian ini adalah metode desriptif kualitatif. Penelitan ini dilaksanakan di SMA Kota Bandar Lampung, dengan subjek penelitian 2 orang siswa kelas $\mathrm{X}$ semester ganjil tahun pelajaran 2018/2019. Pemilihan subjek penelitian didasarkan pada beberapa kriteria, yaitu (1) siswa tersebut telah mendapatkan materi persamaan dan pertidaksamaan nilai mutlak linier satu variabel; (2) siswa sudah memiliki pengalaman belajar yang cukup sehingga diharapkan dapat menyelesaikan soal-soal pada materi persamaan dan pertidaksamaan nilai mutlak linier satu variabel; (3) siswa kelas $\mathrm{X}$ dimungkinkan mampu mengkomunikasikan pemikirannya secara lisan maupun tulisan dengan baik; dan (4) ketersediaan peserta didik untuk menjadi subjek. Pengambilan subjek menggunakan tekhnik purposive random sampling.

Prosedur pemilihan subjek dalam penelitian ini, yaitu (1) menyiapkan tes Myer-Briggs Type Indicator (MBTI); (2) memberikan tes MBTI kepada seluruh peserta didik kelas X; (3) mengelompokkan siswa berdasarkan dimensi Myer-Briggs; (4) memilih 2 subjek penelitian berdasarkan dimensi kepribadian Myer-Biggs;

mengelompokkan subjek ke dalam tipe kepribadian; (6) menetapkan kriteria pemilihan subjek penelitian; dan (7) memilih subjek penelitian. pengumpulan data dalam penelitian ini dilakukan dengan cara memberikan tes tertulis dan wawancara dari hasil yang telah dikerjakan subjek, yaitu: (a) memilih 2 orang siswa yang terdiri dari 1 orang siswa dengan tipe kepribadian guardian dan 1 siswa dengan tipe kepribadian idealist; (b) menentukan waktu pengambilan data dengan meminta saran guru matematika dengan mempertimbangkan waktu dan jadwal belajar; (c) melaksanakan pengambilan data pertama kemampuan komunikasi matematis dengan cara meminta siswa untuk menyelesaikan soal tes komunikasi matematis yang diberikan; (d) pengambilan data kedua yaitu wawancara dengan memberikan pertanyaan-pertanyaan yang bertujuan untuk melihat kemampuan komunikasi matematis siswa dan menggunakan alat bantu audio recorder.; (e) menganalisis data 2 orang siswa tersebut; (f) melaksanakan pengambilan data kedua, dengan tujuan untuk melihat validitas data pada pengambilan data pertama; (g) membandingkan hasil pengambilan data pertama dan kedua dari masing-masing subjek penelitian; (h) menyimpulkan hasil analisis kemampuan komunikasi matematis siswa pada data pertama yaitu tes tertulis dengan data kedua yaitu wawancara dari masing-masing subjek penelitian; (i) membandingkan hasil analisis data pada masing-masing subjek penelitian untuk mendapatkan kesimpulan data kemampuan komunikasi matematis pada masing-masing tipe kepribadian.

Untuk mendapatkan data kemampuan komunikasi matematis siswa digunakan instrumen utama dan instrumen bantu. Instrumen utama dalam penelitian ini adalah peneliti sendiri yang mengumpulkan data secara langsung dengan sumber data. Instrumen bantu berupa soal kemampuan komunikasi matematis dan pedoman wawancara. Teknik analisis 
data dalam penelitian dilakukan dengan cara: (1) menelaah seluruh data yang tersedia dari berbagai sumber, seperti dari hasil wawancara dan data tertulis, dan pengamatan yang sudah dituliskan dalam catatan lapangan, kemudian mereduksi data, yaitu dengan memilih hal-hal pokok yang sesuai dengan fokus penelitian; (2) menyajikan data dalam teks naratif; dan (3) menyimpulkan kemampuan komunikasi matematis berdasarkan masing-masing tipe kepribadian. Untuk mempermudah proses analisis data dan pembahasan, 2 orang siswa tersebut diberi keterangan sebagai berikut: siswa dengan inisial NAP yaitu siswa dengan tipe kepribadian guardian dan siswa dengan inisial DBD yaitu siswa dengan tipe kepribadian idealist.

\section{HASIL DAN PEMBAHASAN}

Pengambilan data dilakukan setelah diperoleh siswa yang memenuhi kriteria subjek penelitian dan didapatkan 2 orang siswa yang terdiri dari 1 orang siswa dengan tipe kepribadian guardian (NAP) dan 1 orang siswa dengan tipe kepribadian idealist (DBD). Selanjutnya melaksanakan pengambilan data kemampuan komunikasi matematis dengan menggunakan wawancara dari hasil tes tertulis komunikasi matematis pada 2 orang siswa tersebut. berdasarkan pengamatan terhadap 2 siswa dari masing-masing tipe kepribadian tersebut, diperoleh 2 rekaman kemampuan komunikasi matematis untuk masing-masing tipe kepribadian yang lengkap dan mendukung untuk mendeskripsikan kemampuan komunikasi matematis. Selanjutnya dilakukan analisis data secara mendalam terhadap hasil rekaman tersebut berdasarkan kriteria kemampuan komunikasi matematis, yaitu: kemampuan menuliskan apa yang diketahui dan ditanyakan pada soal, kemampuan menuliskan jawaban sesuai dengan maksud soal, kemampuan membuat alasan-alasan dalam menjawab soal, kemampuan membuat gambar yang relevan dengan soal, kemampuan menuliskan istilah-istilah dan simbolsimbol matematika, dan kemampuan membuat simpulan dengan bahasa sendiri.

Setelah menganalisis hasil wawancara tentang kemampuan komunikasi matematis peserta didik pada pengambilan data pertama, selanjutnya melakukan pengambilan data yang kedua. Hal ini dilakukan untuk melihat validitas data kemampuan komunikasi matematis siswa pada pengambilan data pertama dengan cara membandingkan hasil pengambilan data pertama dengan hasil pengambilan data kedua. Selanjutnya jika terdapat data yang berbeda maka akan direduksi. Sehingga dapat disimpulkan gambaran hasil kemampuan komunikasi matematis berdasarkan masing- masing tipe kepribadian. Analisis data kemampuan komunikasi matematis pada masingmasing subjek penelitian 1 orang siswa yang mempunyai tipe kepribadian guardian dan 1 orang siswa dengan tipe kepribadain idealist, berdasarkan kriteria kemampuan komunikasi matematis, maka diperoleh data kemampuan komunikasi matematis siswa dalam pemecahan masalah matematika yang valid. Adapun data kemampuan komunikasi matematis yang valid untuk siswa dengan tipe kepribadian guardian disajikan pada Tabel 1.

Tabel 1. Data Kemampuan Komunikasi Matematis Siswa yang Valid dengan Tipe Kepribadian Guardian (NAP) 
Desimal, 1 (3), 2018 - 341

Lekok Melya, Nanang Supriadi

\begin{tabular}{|c|c|c|}
\hline $\begin{array}{c}\text { Kriteria kemampuan } \\
\text { komunikasi matematis }\end{array}$ & $\begin{array}{c}\text { Kemampuan komunikasi } \\
\text { Matematis Tahap Tes Tertulis }\end{array}$ & $\begin{array}{c}\text { Kemampuan komunikasi } \\
\text { Matematis Tahap } \\
\text { Wawancara }\end{array}$ \\
\hline $\begin{array}{l}\text { Kemampuan menuliskan apa yang } \\
\text { diketahui dan ditanyakan pada } \\
\text { soal }\end{array}$ & $\begin{array}{l}\text { Siswa mampu menuliskan apa } \\
\text { yang diketahui dan ditanyakan } \\
\text { pada soal dengan benar dan } \\
\text { tepat. }\end{array}$ & $\begin{array}{l}\text { Siswa mempu menuliskan apa } \\
\text { yang diketahui dan } \\
\text { ditanyakan pada soal dengan } \\
\text { benar dan tepat. }\end{array}$ \\
\hline $\begin{array}{l}\text { Kemampuan menuliskan jawaban } \\
\text { sesuai dengan maksud soal }\end{array}$ & $\begin{array}{l}\text { Siswa mampu menuliskan } \\
\text { jawaban sesuai dengan maksud } \\
\text { soal, dan siswa mampu } \\
\text { membuat langkah-langkah } \\
\text { penyelesaian dalam } \\
\text { mengerjakan soal. }\end{array}$ & $\begin{array}{l}\text { Siswa mampu menuliskan } \\
\text { jawaban sesuai dengan } \\
\text { maksud soal, dan siswa } \\
\text { mampu membuat langkah- } \\
\text { langkah penyelesaian dalam } \\
\text { mengerjakan soal. }\end{array}$ \\
\hline $\begin{array}{l}\text { Kemampuan menuliskan alasan- } \\
\text { alasan dalam menjawab soal }\end{array}$ & $\begin{array}{l}\text { Siswa mampu membuat alasan- } \\
\text { alasan dalam menjawab soal } \\
\text { dengan benar dan tepat }\end{array}$ & $\begin{array}{l}\text { Siswa sempat merasa } \\
\text { kesulitan dalam mengerjakan } \\
\text { soal, namun subjek ini bisa } \\
\text { menyelesaikan soal tersebut, } \\
\text { walaupun butuh waktu untuk } \\
\text { mengingat-ingat kembali } \\
\text { materi itu. }\end{array}$ \\
\hline $\begin{array}{l}\text { Kemampuan membuat gambar } \\
\text { yang relevan dengan soal }\end{array}$ & $\begin{array}{l}\text { Siswa mampu membuat gambar } \\
\text { yang relevan dengan soal. }\end{array}$ & $\begin{array}{l}\text { Siswa mampu membuat } \\
\text { gambar yang relevan dengan } \\
\text { soal. }\end{array}$ \\
\hline $\begin{array}{l}\text { Kemampuan menuliskan istilah- } \\
\text { istilah dan simbol-simbol } \\
\text { matematika }\end{array}$ & $\begin{array}{l}\text { Siswa mampu menuliskan } \\
\text { istilah-istilah dan simbol-simbol } \\
\text { matematika dari bentuk soal } \\
\text { cerita. }\end{array}$ & $\begin{array}{l}\text { Siswa mampu menjelaskan } \\
\text { istilah-istilah dan simbol- } \\
\text { simbol matematika dari } \\
\text { bentuk soal cerita. }\end{array}$ \\
\hline $\begin{array}{l}\text { Kemampuan membuat simpulan } \\
\text { secara tertulis menggunakan } \\
\text { bahasa sendiri }\end{array}$ & $\begin{array}{l}\text { Siswa tidak menuliskan } \\
\text { jawaban dari soal nomor } 3 .\end{array}$ & $\begin{array}{l}\text { Siswa sangat kurang dalam } \\
\text { membuat simpulan dengan } \\
\text { bahasa sendiri, siswa } \\
\text { kesulitan dalam membuat } \\
\text { kata-kata dalam membuat } \\
\text { kesimpulan. }\end{array}$ \\
\hline
\end{tabular}

Jadi, berdasarkan tabel 1 dapat disimpulkan bahwa siswa dengan tipe kepribadian Guardian pada kriteria 1 siswa mampu menuliskan apa yang diketahui dan ditanyakan pada soal dengan benar dan tepat, pada kriteria 2 siswa mampu menuliskan jawaban sesuai dengan maksud soal, kriteria 3 siswa mampu membuat alasan-alasan dalam menjawab soal dengan benar dan tepat, kriteria 4 siswa mampu membuat gambar yang relevan dengan soal, kriteria 5 siswa mampu menuliskan istilah-istilah dan simbol-simbol matematika dari bentuk soal cerita, dan kriteria 6 siswa kurang mampu dalam membuat simpulan dengan bahasa sendiri.

Tabel 2. Data Kemampuan Komunikasi Matematis Siswa yang Valid dengan Tipe Kepribadian Idealist (DBD)

\begin{tabular}{lll}
\hline \multicolumn{1}{c}{$\begin{array}{c}\text { Kriteria kemampuan } \\
\text { komunikasi matematis }\end{array}$} & $\begin{array}{c}\text { Kemampuan komunikasi } \\
\text { Matematis Tahap Tes Tertulis }\end{array}$ & $\begin{array}{c}\text { Kemampuan komunikasi } \\
\text { Matematis Tahap } \\
\text { Wawancara }\end{array}$ \\
$\begin{array}{l}\text { Kemampuan menuliskan apa yang } \\
\text { diketahui dan ditanyakan pada } \\
\text { soal }\end{array}$ & $\begin{array}{l}\text { Siswa mampu menuliskan apa } \\
\text { yang diketahui dan ditanyakan } \\
\text { pada soal dan Siswa mampu } \\
\text { menyelesaikan soal dengan } \\
\text { tepat. }\end{array}$ & $\begin{array}{l}\text { Siswa dapat menuliskan apa } \\
\text { yang diketahui dan } \\
\text { ditanyakan pada soal. }\end{array}$ \\
$\begin{array}{l}\text { Kemampuan menuliskan jawaban } \\
\text { sesuai dengan maksud soal }\end{array}$ & $\begin{array}{l}\text { Siswa mampu menjawab soal } \\
\text { sesuai dengan maksud soal. }\end{array}$ & $\begin{array}{l}\text { Siswa mampu menjawab soal } \\
\text { dengan benar, walaupun } \\
\text { peserta didik sempat merasa }\end{array}$ \\
\hline
\end{tabular}


Desimal, 1 (3), 2018 - 342

Lekok Melya, Nanang Supriadi

Kriteria kemampuan
komunikasi matematis alasan dalam menjawab soal

Kemampuan membuat gambar yang relevan dengan soal

Kemampuan menuliskan istilahistilah dan simbol-simbol matematika

Kemampuan membuat simpulan secara tertulis menggunakan bahasa sendiri

Kemampuan komunikasi
Matematis Tahap Tes Tertulis

Siswa tidak memberikan alasan-alasan dalam menjawab soal

Siswa mampu membuat gambar grafik yang relevan dengan soal.

Siswa masih salah dalam menuliskan simbol-simbol matematika. Seharusnya peserta didik menggunakan simbol " < " dan simbol " > ", tetapi peserta didik menggunakan simbol " $\leq$ "dan $" \geq "$.

Kemampuan siswa dalam membuat simpulan secara tertulis dengan bahasa sendiri masih kurang tepat.

Kemampuan komunikasi Matematis Tahap Wawancara

kesulitan dalam menentukan batas nilai $\mathrm{x}$, siswa membutuhkan waktu untuk mengingat kembali proses pengerjaan soal tersebut. Siswa kurang mampu dalam menuliskan alasan-alasan dalam menjawab soal terlihat saat peserta didik menjawab soal nomor 4, siswa hanya menjawab benar saja dan salah saja tanpa memberikan alasan sesuai dengan maksud soal.

Siswa mampu membuat gambar yang relevan dengan soal. Siswa mampu mengekspresikan ide-ide matematika kedalam bentuk gambar.

Siswa mampu menuliskan istilah-istilah dari bentuk soal cerita, namun masih salah dalam penggunaan simbol yang digunakan seharusnya menggunakan simbol " < " dan simbol " > ", tetapi subjek menggunakan simbol " $\leq$ " dan " $\geq$ ".

Kemampuan siswa dalam membuat simpulan secara tertulis dengan bahasa sendiri masih kurang tepat. siswa kurang mampu dalam mengembangkan kata-kata dengan bahasanya sendiri, walaupun siswa mampu membaca gambar yang telah dibuatnya, hanya saja kesulitan dalam mengembangkan kata-kata.

Jadi berdasarkan tabel 2 dapat disimpulkan bahwa siswa dengan tipe kepribadian Idealist pada kriteria 1 peserta didik mampu menuliskan apa yang diketahui dan ditanyakan pada soal dengan benar dan tepat, kriteria 2 siswa mampu menuliskan jawaban sesuai dengan maksud soal, kriteria 3 siswa kurang mampu membuat alasan-alasan dalam menjawab soal dengan benar dan tepat, kriteria 4 siswa mampu membuat gambar yang relevan dengan soal, kriteria 5 siswa mampu menuliskan istilah-istilah

dan simbol-simbol matematika dari bentuk soal cerita, dan kriteria 6 siswa mampu dalam membuat simpulan dengan bahasa sendiri.

\section{Kemampuan Komunikasi Matematis Siswa dengan Tipe Kepribadian Guardian}

Berdasarkan hasil deskripsi dan hasil analisis di atas dapat disimpulkan bahwa kecendrungan kemampuan komunikasi matematis siswa yang memiliki tipe kepribadian guardian 
dalam mengerjakan soal mampu menuliskan informasi yang ada dalam soal sambil membaca soal, dengan sangat memahami maksud dari soal tersebut, subjek membaca soal dengan berulangulang untuk dapat memahaminya, subjek juga sempat berhenti beberapa kali dalam mengerjakan soal tersebut. Subjek mampu menuliskan apa yang diketahui dan ditanyakan pada soal dengan benar dan tepat. Subjek tidak merasa kesulitan dalam menemukan informasi pada soal karena sudah terbiasa saat mengerjakan soal melalui latihan-latihan yang diberikan oleh pengajar saat pelajaran berlangsung, hal tersebut mampu meningkatkan kemampuan komunikasi matematis peserta didik.

Subjek dengan tipe guardian mampu menuliskan jawaban sesuai dengan maksud soal. Subjek ini mampu membuat langkah-langkah penyelesaian dalam mengerjakan soal. Subjek ini juga menuliskan alasan-alasan dalam menjawab soal nomor 5, subjek ini mampu menguraikan alasan-alasannya dengan tepat dan jelas, hasil wawancara juga menunjukkan bahwa subjek ini sempat merasa kesulitan dalam mengerjakan soal, namun subjek ini bisa menyelesaikan soal tersebut, walaupun butuh waktu untuk mengingat-ingat kembali materi yang telah dijelaskan pendidik sebelumnya.

Subjek guardian menunjukkan sifat cooperative dalam membuat gambar yang relevan dengan soal. Cara subjek dalam menggambar sama dengan kebanyakan orang. Subjek menggambarkan bentuk persamaan dengan membuat bayangan garis putus-putus untuk mendapatkan titik temu untuk memudahkah dalam membuat grafik sesuai dengan perintah soal, sehingga menghasilkan gambar grafik yang sesuai dan tepat. Subjek ini juga tidak merasa kesulitan dalam menuliskan istilah-istilah dan simbol matematika, walaupun subjek ini lebih suka berbicara, tapi guardian sangat mudah belajar bila diberi pengulangan dan latihan-latihan menuliskan istilahistilah dan simbol-simbol matematika.

Subjek dengan tipe kepribadian guardian ini sangat kurang dalam membuat simpulan dengan bahasa sendiri, hasil wawancara menunjukkan bahwa subjek ini mengaku bahwa ia kesulitan dalam membuat kata-kata dalam membuat simpulan dengan bahasa sendiri.

\section{Kemampuan Komunikasi Matematis Siswa dengan Tipe Kepribadian Idealist}

Berdasarkan hasil deskripsi dan hasil analisis di atas dapat disimpulkan bahwa kecendrungan kemampuan komunikasi matematis siswa yang memiliki tipe kepribadian idealist dalam mengerjakan soal mampu menuliskan informasi yang ada dalam soal, membaca soal dengan teliti untuk memahami maksud dari soal tersebut. Subjek mampu menuliskan apa yang diketahui dan yang ditanyakan pada soal, subjek juga mampu menterjemahkan maksud dari soal cerita tersebut dan mampu menyimpulkan hasil dari jawaban yang telah diuraikan.

Subjek mampu menuliskan jawaban sesuai dengan maksud soal, dari hasil wawancara bahwa subjek mampu menjawab soal dengan benar, walaupun Subjek sempat merasa kesulitan dalam menentukan batas nilai $\mathrm{x}$, subjek membutuhkan waktu untuk mengingat kembali proses pengerjaan soal tersebut. Subjek kurang mampu dalam menuliskan alasan-alasan dalam menjawab soal terlihat saat subjek menjawab soal nomor 4, subjek hanya menjawab benar saja dan salah saja tanpa memberikan alasan sesuai dengan maksud soal. Subjek juga mampu membuat gambar yang relevan dengan soal, subjek mampu menggambar grafik dengan benar, subjek dapat menuliskan konsep awal dalam menentukan nilai $x$ dan $y$ dari persamaan serta mampu membuat gambar yang 
sesuai dengan soal, sehingga dari hasil tes dan wawancara menunjukkan bahwa subjek mampu mengekspresikan ide-ide matematis kedalam bentuk gambar.

Subjek idealist dalam menuliskan istilah-istilah dan simbol-simbol matematika sudah baik namun sedikit kurang teliti sering terjadi kesalahan dalam penulisan simbol. Hasil wawancara terkait hal tersebut menunjukkan bahwa subjek mampu menuliskan jawaban dari bentuk soal cerita, namun masih salah dalam penggunaan simbol yang digunakan seharusnya menggunakan simbol "<" dan simbol ">", tetapi subjek menggunakan simbol " $\leq$ " dan $" \geq "$. Kemampuan subjek dalam membuat simpulan secara tertulis dengan bahasa sendiri masih kurang tepat. Subjek kurang mampu dalam mengembangkan kata-kata dengan bahasanya sendiri, walaupun subjek mampu membaca gambar yang telah dibuatnya, hanya saja kesulitan dalam mengembangkan bahasanya.

\section{SIMPULAN DAN SARAN}

Berdasarkan hasil analisis data dari 2 subjek penelitian tersebut maka dapat disimpulkan sebagai berikut: (1) Kemampuan komunikasi matematis dari tipe kepribadian Guardian (NAP) yaitu (a) siswa tipe guardian mampu menuliskan apa yang diketahui dan ditanyakan pada soal dengan lengkap, benar, dan tepat, (b) siswa tipe guardian mampu menuliskan jawaban yang sesuai dengan maksud soal, (c) siswa tipe guardian mampu menuliskan alasan-alasan dalam menjawab soal dengan benar dan tepat, (d) siswa tipe guardian mampu membuat gambar yang relevan dengan soal, (e) siswa tipe guardian mampu menuliskan istilah-istilah dan simbol-simbol matematika dalam menjawab soal dengan benar dan tepat, dan (f) siswa tipe guardian tidak mampu dalam membuat simpulan secara tertulis dengan bahasa sendiri; (2) Kemampuan komunikasi matematis dari tipe kepribadian Idealist, yaitu (a) siswa tipe Idealist mampu menuliskan apa yang diketahui dan ditanyakan pada soal dengan lengkap, benar, dan tepat, (b) siswa tipe Idealist mampu menuliskan jawaban yang sesuai dengan maksud soal, (c) siswa tipe Idealist tidak mampu menuliskan alasanalasan dalam menjawab soal, (d) siswa tipe Idealist mampu membuat gambar yang relevan dengan soal, (e) siswa tipe Idealist mampu menuliskan istilah-istilah dan simbol-simbol matematika dalam menjawab soal namun kurang tepat, (f) siswa tipe Idealist mampu dalam membuat simpulan secara tertulis dengan bahasa sendiri namun kurang tepat.

Adapun saran dari penelitian ini adalah sebagai berikut: (1) Bagi sekolah, dengan adanya hasil penelitian ini hendaknya dapat dijadikan sebagai masukan dan pertimbangan sebagai salah satu bahan alternatif dalam kemajuan semua mata pelajaran terutama matematika serta dapat digunakan sebagai acuan untuk lebih meningkatkan kemampuan komunikasi matematis peserta didik; (2) Bagi guru matematika, sebagai masukan untuk lebih membantu peserta didik dalam pembentukan dan pembiasaan untuk meningkatkan kemampuan komunikasi matematis yang baik; (3) Bagi peserta didik, hendaknya dijadikan sebagai motivasi untuk mengembangkan kemampuan komunikasi matematis mereka dan menelaah tipe kepribadian yang mereka miliki untuk dapat menyesuaikan dalam segala bidang mata pelajaran; (4) Bagi penulis, hendaknya dapat menambah pengetahuan dan pengealaman dalam menerapkan ilmu pengetahuan yang diperoleh di bangku kuliah terhadap masalah yang dihadapi di dunia pendidikan secara nyata dan menjadi bekal dimasa mendatang serta dapat melaksanakan penelitian lebih lanjut; dan (5) Bagi peneliti selanjutnya, setelah diketahuinya karakteristik kemampuan 
komunikasi matematis siswa dengan tipe tertentu, penelitian dapat dilanjutkan dengan model pembelajaran matematika yang sesuai berdasarkan penggolongan tipe kepribadian, serta perangkat pembelajaran yang sesuai dengan model pembelajaran.

\section{DAFTAR PUSTAKA}

Aziz, A., Kusmayadi, T. A., \& Sujadi, I. (2014). Proses Berpikir Kreatif dalam Pemecahan Masalah Matematika Ditinjau dari Tipe Kepribadian Dimensi Myer-Briggs Siswa Kelas VIII MTs Nw Suralaga Lombok Timur Tahun Pelajaran 2013/2014. Jurnal Elektronik Pembelajaran Matematika ISSN: 2339-1685, 2(10), 1079-1093.

Bulu, V. R., \& Slamet, I. (2015). Kesulitan Metakognisi Siswa dalam Memecahkan Masalah Matematika Pada Materi Peluang Ditinjau dari Tipe Kepribadian Tipologi Hippocrates - Galenus Kelas XI MIA 1 SMA Negeri I Soe. Jurnal Elektronik Pembelajaran Matematika, 3(9), 970-984.

Fitria, C., Sujadi, I., \& Subanti, S. (2016). Analisis Kesulitan Metakognisi Siswa dalam Memecahkan Masalah Sistem
Pertidaksamaan Linear Dua Variabel Ditinjau dari Tipe Kepribadian Guardian, Artisan, Rational, dan Idealist Kelas X SMKN I Jombang. Jurnal Elektronik Pembelajaran Matematika, 4(9), 824-835.

Hasanah, U., \& Putra, R. W. Y. (2017). Analisis Proses Berpikir Kreatif dalam Memecahkan Masalah Matematika Ditinjau dari Tipe Kepribadian Rational dan Artisan. Prosiding Seminar Nasional Pendidikan Matematika P-ISSN : 2579-941X E-ISSN : 2579-9444, 137149.

Supriadi, N. (2015). Pembelajaran Geometri Berbasis Geogebra Sebagai Upaya Meningkatkan Kemampuan Komunikasi Matematis. Al-Jabar: Jurnal Pendidikan Matematika, 6(2), 99-109.

Syahri, A. A. (2017). Pengaruh Penerapan Pendekatan Realistik Setting Kooperatif Terhadap Kemampuan Komunikasi Matematika Siswa Kelas VIII. MaPan : Jurnal Matematika Dan Pembelajaran, 5(2), 216-235. 